\title{
Utilization of Crop Corn Waste as a Complete Feed for Pregnant Goats \\ by Dian Wahyu Harjanti
}

Submission date: 17-Jan-2020 03:29PM (UTC+0700)

Submission ID: 1243002761

File name: Anis_Muktiani_Advanced_Science_Letter_1.pdf (160.11K)

Word count: 2168

Character count: 10417 


\title{
Utilization of Crop Corn Waste as a Complete Feed for Pregnant Goats
}

\author{
Muktiani, Anis; Kusumanti Endang; Harjanti, Dian Wahyu \\ Faculty of Animal and Agricultural Sciences, Diponegoro University, Semarang, Indonesia. \\ *Corresponding author email: anis.muktiani@gmail.com
}

\begin{abstract}
Corn plantation area in Indonesia reached 3.9 million hectares and produce corn plants waste approximately 87.5 million tons/year. This waste must be managed properly so as not to cause environmental problems. This study aimed to assess the utilization of corn straw as a complete feed for pregnant goats. Sixteen pregnant goats resulted from artificial insemination were used for this experiment. Design of the study was $2 \times 2$ factorial pattern with 4 replications. Four combinations of treatment are: T1S0 $=$ ration of $28 \%$ corn straw (CP 14\%, TDN 65\%), T1S1 = T1+mineral Zinc and Folic Acid, T2S0 = ration with 22\% corn straw (CP $16 \%$, TDN $67 \%$ ), T2S1 = T2+mineral Zinc and Folic Acid. Complete feed rations in the form of dry mash, given for 18 weeks. The results showed that there was no interaction between the treatment i.e., ration quality with mineral supplementation of zinc and folic acid. The analysis with Duncan Multiple Range Test showed that the diet containing of $28 \%$ corn straw (CP $14 \%$, TDN $65 \%$ ) resulted in dry matter intake and daily body weight of pregnant goats which were higher than the diet containing of $22 \%$ corn straw (CP $16 \%$, TDN 67\%). While the mineral supplementation of zinc and folic acid did not affect both parameters. The T1S1 ration is the best among treatment applied according to dry matter intake and body weight gain which were reaching $823.63 \mathrm{~g} / \mathrm{d}$ and $85.39 \mathrm{~g} / \mathrm{d}$. The conclusion of this study was the use of $28 \%$ corn straw in rations eligible for pregnant goats.
\end{abstract}

Keywords : Body Weight Gain; Corn Straw; Dry Matter Intake; Pregnant Goats

\section{INTRODUCTION}

Corn production in Indonesia reached 19 million tons / year, it is the eighth ranks in the world corn production1. Data from the Directorate of Food and Agriculture in 2014, shows that the width of corn crop land of 3.96 hectares approximately, therefore it can be estimated that the production of fresh corn crop waste reach 87.5 million tons/year or 20.49 million tones of dry matter/year ${ }^{2}$ This enormous waste production needs to be handled properlyso it might not be cause environmental problems. Among other ways is by using it as feedstuff material for composing complete feed for goats.

Etawa crossbred goat is a kind of sizable number of animals kept in Indonesia. In the period of pregnancy the female goat requires sufficient nutrients in order to produce a healthy offspring. A shortage of macro nutrients such as protein and energy will cause low birth weigh as well as production and quality of milk will be below standard ${ }^{3}$ Besides, the pregnant goats also need vitamins and minerals, including folic acid and minerals $\mathrm{Zinc}(\mathrm{Zn})$.

Folic acid is a vitamin that is needed in nucleic acid synthesis. Insufficent folic acid will inhibit the nucleic acid synthesis and it causes the failure of cells to fascilitate DNA to replicate.This situation make the synthesis of proteins, lipids and myelin hampered and these can disturbthe process of embryogenesis as related to fetal and maternal fertility ${ }^{4}$

Mineral $\mathrm{Zn}$ is known as a trace mineral that is a 9 nstituent of the 300 kinds of enzymes, involved in the metabolism of proteins, amino acids, nucleic acids, lipids, carbohydrates and vitamins as well as build up the immune system $^{56}$. The aim of this study was to find the right formulation ofration based on corn stoverwith the proper protein and energy content, and to test the supplementation of folic acid and zinc on pregnant goats upon the body weight gain.

\section{EXPERIMENTAL DETAILS}

The study was conducted over 8 period of four months from April to July 2016 at the Faculty of Animal and Agricultural Sciences, Diponegoro University. The altitude of the location was $+100 \mathrm{~m}$ above sea level and the temperature was around $30^{\circ}-33^{\circ} \mathrm{C}$. Sixteen female goats of \pm lyear old with $30 \pm 2.14 \mathrm{~kg}$ were used in this study. The animals were placed in individual cages equipped with 
feed and water. Every two weeks the animals were weighed on digital scales with the capacity of $150 \mathrm{~kg}$ and with 0.01 $\mathrm{kg}$ of precision. The compositions of the treatment ration are shown in Table 1.

The experimental design used was complete randomized design factorial pattern of $2 \times 2$. The first factor was 2 levels of the ration qualit 4 (T1 $=\mathrm{CP} 14 \%$, TDN $65 \%$ and $\mathrm{T} 2=\mathrm{CP} 16 \%$, TDN $67 \%$ ), while the second factor was the $\mathrm{S} 0=$ without supplementation and $\mathrm{S} 1=$ supplemented with minerals and vitamins needed for fetal growth (zinc and folic acid). Four combinations of these treatments are:

T1S0: ration with CP14\%, TDN $65 \%$

T1S1: ration with CP $14 \%$, TDN $65 \%+$ Zn $30 \mathrm{ppm}$ and folic acid $200 \mu \mathrm{g}$

T2S0: ration with CP16\%, TDN $67 \%$

T2S1: ration with CP16\%, TDN $67 \%+\mathrm{Zn} 30 \mathrm{ppm}$ and folic acid $200 \mu \mathrm{g}$.

\section{TABLE 1. COMPOSITION OF DIETARY TREATMENT}

T1 : ration of $28 \%$ corn straw (CP $14 \%$, TDN $65 \%$ )

T2: ration of $22 \%$ corn straw (CP 16\%, TDN $67 \%$ )

Parameters measured were: 1) the feed dry matter intake, it is measured by substracting the amount of given feedstuff to the remaining feedstuff the next day; 2) daily weight gain,it is measured by substracting the final body

\begin{tabular}{lrr}
\hline Feedstuff & T1 & T2 \\
\hline & 28 & 22 \\
Corn stover & 23 & 20 \\
Rice meal & 6 & 7 \\
Cassava proccesed waste & 22 & 20 \\
Pollard & 8 & 13 \\
Soybean meal & 10 & 15 \\
Cocconut meal & 3 & 3 \\
Molasses & $\mathbf{1 0 0}$ & $\mathbf{1 0 0}$ \\
TOTAL & & \\
Nutrient contents: & 14.01 & 16.27 \\
Crude Protein & 6.03 & 67.51 \\
Total Digestible Nutrients & 9.55 & 9.26 \\
Ash & 5.64 & 5.91 \\
Extract Ether & 20.80 & 18.80 \\
Crude Fiber & 51.49 & 50.94 \\
Nitrogen Free Extract & 40.89 & 39.27 \\
Neutral Detergent Fiber & 22.29 & 21.23 \\
Acid Detergent Fiber &
\end{tabular}

weight with the initial body weight then divided by the length of maintenance; 3 ) feed conversion is the amount of required feedstuff to produce $1 \mathrm{~kg}$ of body weight; 4) feed efficiency, is the weight gain that produced fro $21 \mathrm{~kg}$ of feedstuff which is expressed as a percentage. Data were analyzed using analysis of variance it will be continued with Duncan multiple range test if there is a finding of significant differences on the previous analysis ${ }^{7}$.

\section{RESULTS AND DISCUSSION}

Dry matter intake and body weight gain of experimental goat are presented in Table 2. Results of analysis of variance shows there were interaction between diet and factor of supplementation quality upon the weight gain, but not for dry matter intake.

Dry matter consumption of thetreated goats ranged from 681.29 to $820.88 \mathrm{~g} / \mathrm{d}$ ( 2.03 to $2.34 \%$ of body weight), it is lower than the standard of required DM according to $\mathrm{NRC}^{8}$, which is $1400-1780 \mathrm{~g} / \mathrm{d}$ for the late pregnant goat with $30-50 \mathrm{~kg}$ of body weight or about 2.4 to $2.7 \%$ of body weight. This is due to the low consumption of feedstuff in the form of dry mash. It showes that DM consumption in the ration with $\mathrm{CP} 16 \%$ and TDN $67 \%$ lower than the feedstuff containing of $\mathrm{CP} 14 \%$ and $65 \%$ TDN. The decline of consumption might be caused by the increasing of 3 ergywhich made those goats feel full within a short time. These results are in line with the results of previous studies that the increase ofration energy will reduce the levels of consumption ${ }^{9}$.

Just as dry matter intake, body weight gains of pregnant goats are low to moderate, ie. between 51.30 $82.42 \mathrm{~g} / \mathrm{head} / \mathrm{d}$. Eight-month-old goats are having immature body physiologically, so that they can increase body weight up to $55 \mathrm{~kg}$ when they are reaching 1 year old. The increase of energy should provide higher VFA in the rumen so that microbes will develop and provide microbial protein forthe animal. But this did not happen in $\mathrm{T} 2$ ration, because TDN and protein ratio in T2 is low (4.1). Other publication found that the TDN and $\mathrm{CP}$ ratio 5 provide better weight gain than $4^{10}$. The smaller ratio between TDN and CP means that the higher content of CP in the diet. Dietary protein in the rumen will be degraded by the rumen microbial enzymes and produced ammonia. Due to the limitation of energy, the microbes cannot utilize the ammonia. Ammonia that is produced but not utilized in the rumen is absorbed, transformed into urea in the liver and returned into the circulation, from where it can return to the rumen via saliva or the rumen wall, and any excess is excreted in the urine. The process of changing ammonia to urea in the liver called ornithine cycle or urea cycle requires great energy. Every formation of one molecule of urea from $\mathrm{CO}_{2}$ and $\mathrm{NH}_{3}$ requires three ATP. This causes a lot of energy is lost. That is why the ratio TDN and CP were small is not efficient.

Based on that finding it can be noted that the ration levels of CP $14 \%$ and TDN $65 \%$ able to produce better body weight gaim11while the minerals zinc and folic acid supplementation did not show any significant differences. Feed conversion in this study ranged from 10.82 to 16.38 , while the feed efficiency ranged from 6.36 to $9.92 \%$, it is better than the finding of other report who got a goat feed conversion of 15.84 to $16.81^{11}$, while recent publication got a goat feed efficiency of 5.2 to $7.1 \%^{12}$. 


\section{RESEARCH ARTICLE}

TABLE 2. DRY MATTER INTAKE CONSUMPTION AND BODY WEIGHT GAIN

\begin{tabular}{ccccc}
\hline Treatment & $\begin{array}{c}\text { DMC } \\
(\mathrm{g} / \mathrm{d})\end{array}$ & $\begin{array}{c}\text { ADG } \\
(\mathrm{g} / \mathrm{d})\end{array}$ & $\begin{array}{c}\text { FC } \\
(\%)\end{array}$ & FE (\%) \\
\hline T1S0 & $820.88^{\mathrm{a}}$ & $82.42^{\mathrm{a}}$ & 10.82 & 9.92 \\
T1S1 & $813.63^{\mathrm{a}}$ & $75.39^{\mathrm{b}}$ & 12.33 & 9.46 \\
T2S0 & $735.07^{\mathrm{b}}$ & $57.94^{\mathrm{c}}$ & 12.72 & 7.90 \\
T2S1 & $681.29^{\mathrm{b}}$ & $51.30^{\mathrm{d}}$ & 16.38 & 6.36 \\
\hline
\end{tabular}

The superscript on the same rows and collums in different letters shows the significane of difference $(\mathrm{p}<0,05)$.

DMC: dry matter consumption; ADG: average daily gain; FC: feed conversion; FE $=$ feed efficiency

T1 S0 $=$ ration of $28 \%$ corn straw (CP $14 \%$, TDN $65 \%)$

$\mathrm{T} 1 \mathrm{~S} 1=\mathrm{T} 1+$ mineral Zinc and Folic Acid

T2S0 $=$ ration with $22 \%$ corn straw (CP $16 \%$, TDN $67 \%$ )

$\mathrm{T} 2 \mathrm{~S} 1=\mathrm{T} 2+$ mineral Zinc and Folic Acid

\section{CONCLUSION}

In conclusion, complete feed made from dried corn straw $28 \%$, CP $14 \%$ TDN $65 \%$ resulted in body weight gain,a good feed conversion and efficiency for pregnant goats. Supplementation with folic acid and $\mathrm{Zn}$ mineral does not change the appearance of pregnant goat production.

\section{ACKNOWLEDGMENTS:}

The author would like to thank Institutions of Research and Community Service Diponegoro University that has funded this research through PNBP funding of 2016 fiscal year.

\section{REFERENCES AND NOTES}

1. P. Ranum, J.P.P. Rosas and M.N.G. Casal.Global maize production, utilization, and consumption.Ann. N.Y. Acad. Sciences 1312, 105-112 (2014).

2. Direktorat Pangan dan Pertanian-Bappenas. 2014. Rencana Pembangunan Jangka Menengah Nasional (RPJMN) Bidang Pangan dan Pertanian 2015-2019.

(www.bappenas.go.id/index.php/download_file/view/15718/ 4661/).

3. I.K. Sutama. Inovasinovasi teknologi reproduksi mendukung pengembangan kambing perah lokal. Pengembangan Inovasi Pertanian 4, 231-2 (2012).

4. A. Fleming and A.J. Copp. Embryonic Folate Metabolism and Mouse Neural Tube Defects. Science. 280, 2107-2109 (1998).

5. X. Fu-yu,., H. Ming-Hai, L. Wen-li, L. Yan-Qin, W. LingLing, S. Jie and Z. Ji-Feng. Effect of different levels of zinc on bloodphysiological and biochemical parameters in studholsteinbulls. Chinese J. Anim. Nutr., 5:19 (2007).

6. Muktiani, A. Penggunaan Hidrolisat Bulu Ayam dan Sorgum serta Suplemen Kromium Organik Untuk Meningkatkan Produksi Susu Pada Sapi Perah. Disertasi Doktor. Sekolah Pascasarjana IPB. Bogor (2002).

7. R.G.D. Steel and J.H. Torrie.Principles and Procedures of Statistic.Mc Grow Hill Book Co. Inc. N.Y.(1981).

8. NRC. Nutrient Requirements of Goats: Angora, Dairy, and Meat Goats in Temperate and Tropical Countries (1981).

9. Y.A. Abdullah and S.M. Hussein SM. Effect of different levels of energy on carcass composition and meat quality of male black goats kids.Livest. Sci. 107 :
70-80 (2007).

10.Abbasi, S.A.; M.A.Vighio; S.A. Soomro; A.B. Kachiwal; 3 A.Gadahi and G. L Wang. 2012. Effect of Different Dietary Energy Levels on the Growth Performance of Kamori Goat Kids. IJAVMS. 6: 473-479

11. Iswoyo dan Widiyaningrum. Pengaruh Jarak Waktu Pemberian Pakan Konsentrat dan Hijauan Terhadap Produktivitas Kambing Peranakan Etawah Lepas Sapih. Jurnal Ilmiah Ilmu-Ilmu Peternakan. XI (2): 70-74 (2008). 10

12. MM. Rahman, R.B. Abdullah, W.E.W. Khadijah, T. 6 akagawa and R. Akashi. 2015. Feed intake and growth performance of goats fed with Napier grass and oil palm frond supplemented with soya waste.J. ofApp.Anim. Research. 53: 256-260 (2015). 
Utilization of Crop Corn Waste as a Complete Feed for Pregnant Goats

ORIGINALITY REPORT

9

$\%$

$4 \%$

$5 \%$

$\%$

SIMILARITY INDEX

INTERNET SOURCES

PUBLICATIONS

STUDENT PAPERS

PRIMARY SOURCES

1 Jefferson Fabiano Werner Koscheck, Joanis

Tilemahos Zervoudakis, Luciana Keiko

Hatamoto Zervoudakis, Luciano da Silva Cabral,

André Alves de Oliveira, João Marcos Beltrame

Benatti, Daniel Marino Guedes de Carvalho,

Renata Pereira da Silva. "Total digestible

nutrient levels in supplements for finishing

steers in the rainy season: nutritional

characteristics and microbial efficiency", Revista

Brasileira de Zootecnia, 2013

Publication

2 garuda.ristekdikti.go.id Internet Source

Abbasi, Saeed, Muzafar Vighio, Saeed Soomro, Allah Kachiwal, Javaid Gadahi, and WANG

Genlin. "Effect of different dietary energy levels on the growth performance of Kamori goat kids", International Journal for Agro Veterinary and Medical Sciences, 2012. 
Muktiani, A, Kusumanti E. "Pengaruh

Pemberian Bungkil Kedelai Dan Suplementasi

Zinc, Selenium Dan Vitamin E Terhadap

Penampilan Estrus Pada Kambing Peranakan

Etawah (The Effect Of Supplementation With

Soybean Meal, Minerals And Vitamins On

Estrus Performance Of Etawah Crossbreed

Goats)", Jurnal Pengembangan Penyuluhan

Pertanian, 2019

Publication

5

media.neliti.com

Internet Source

$1 \%$

6 Zawawi Daud, Mohd Zainuri Mohd Hatta,

Angzzas Sari Mohd Kassim, Ashuvila Mohd

Aripin, Halizah Awang. " Analysis of Napier

grass ( ) as a potential alternative fibre in paper

industry ", Materials Research Innovations, 2014

Publication

7 ijas.pagepress.org

Internet Source

$8 \quad$ www.veterinaryworld.org

Internet Source

9 scholarworks.uvm.edu

Internet Source

10 J.O. Daramola, E.O. Adekunle, O.S. Iyasere,

O.E. Oke et al. "Effects of coconut milk alone or 
supplementation with pyridoxine in tris-

extenders on viability of buck spermatozoa

during vitrification", Small Ruminant Research,

2016

Publication

11

www.yumpu.com

Internet Source

$<1 \%$

Exclude quotes

On

Exclude bibliography

On
Exclude matches

Off 